\title{
EVOLUTION OF IgG ANTIBODY RESPONSE AGAINST Toxoplasma gondii TISSUE CYST IN ACUTE AND CHRONIC HUMAN INFECTIONS
}

\author{
Margarita VILLAVEDRA(1), Hernán CAROL(2) \& Alberto NIETO(1)
}

\begin{abstract}
SUMMARY
The recognition profile of the tissue cysts antigens by IgG antibodies was studied during acute and chronic human toxoplasmic infection. Thus the IgG response against Toxoplasma gondii was investigated by immunoblotting in two patients accidentally infected with the RH strain as well as in group of naturally infected patients at acute and chronic phase. There was an overall coincidence of molecular mass among antigens of tachyzoites and tissue cysts recognized by these sera, however, they appear not to be the same molecules. The response against tissue cysts starts early during acute infection, and the reactivity of antibodies is strong against a wide range of antigens. Six bands (between 82 and $151 \mathrm{kDa}$ ) were exclusively recognized by chronic phase sera but only the $132 \mathrm{kDa}$ band was positive in more than $50 \%$ of the sera analysed. A mixture of these antigens could be used to discriminate between the two infection phases. The most important antigens recognized by the acute and the chronic phase sera were 4 clusters in the ranges 20-24 kDa, 34-39 kDa, 58-80 kDa and 105-130 kDa as well as two additional antigens of 18 and $29 \mathrm{kDa}$. Both accidentally infected patients and some of the naturally infected patients showed a weak specific response against tissue cyst antigens.
\end{abstract}

KEYWORDS: T.gondii; Tissue cyst; Bradyzoite antigens; Diagnosis; Acute phase; Chronic phase.

\section{INTRODUCTION}

Toxoplasmosis is a universally distributed zoonosis produced by the protozoan Toxoplasma gondii. The infection caused by this parasite is common in many warm-blooded animals, including humans, and it occurs by the ingestion of tissue cysts (in raw meat) or of viable oocysts (in cat faeces). The infection in pregnant women can, in turn, produce acute infection of the foetus by tachyzoite invasion through the placenta and passage to embrionary tissue. This can produce a broad array of consequences, some of them as critical as abortion, malformation, particularly affecting the nervous tissue, bringing about blindness and perinatal death. In immunocompromised patients, particularly those with acquired immunodeficiency syndrome (AIDS), the infection causes toxoplasmic encephalitis and even death. Currently in Europe, $25 \%$ to $50 \%$ of the deaths of AIDS patients are caused by this protozoan infection ${ }^{12}$.

The injuries of the host by the parasite occur during the acute phase of a prime infection, or a recrudescence of a past infection. It is therefore important to discriminate be- tween acute and chronic disease. An approach to deal with this matter is to search for serum antibodies (Ab) distinctly recognizing tachyzoite or tissue cyst antigen $(\mathrm{Ag})$ as markers of acute and chronic disease, respectively. Since the acute infection is characterized by the presence of tachyzoite and the chronic phase by the presence of tissue cyst, the search for specific antibodies to tissue cyst Ag with potential value as discriminative stage markers seems promising in order to improve serology. The human $\mathrm{Ab}$ response against tachyzoite $\mathrm{Ag}$ has been extensively characterized $\mathrm{d}^{3,9,11,13,16}$ in contrast to the response against tissue cyst Ag. The existence of stage specific $\mathrm{Ag}$ has been confirmed by immunofluorescence, immunoblot analysis and ELISA in infected ${ }^{8,17,19}$ as well as in immunized animals ${ }^{4,6}$ or with monoclonal antibodies $(\mathrm{mAb})^{4,14}$.

In human infection, changes in $\mathrm{Ag}$ profiles have also been reported ${ }^{8,18.20}$ but little is known about the $\mathrm{Ab}$ response against parasite developmental stage $\mathrm{Ag}$ associated to the infection phase.

MAKIOKA et al. ${ }^{8}$ identified different clusters (54-63 $\mathrm{kDa}$ and 26-29 $\mathrm{kDa}$ ) of Ag expressed by bradyzoites of the

(1) Cátedra de Inmunologia, Facultad de Química, Montevideo, Uruguay.

(2) Laboratorio de Inmunologia, Facultad de Ciencias Exactas y Naturales, Universidad de la República, Montevideo, Uruguay.

Correspondence to: Q.F. Margarita Villavedra, Cátedra de Inmunologia, Facultad de Química, Casilla de Correos 1157, Montevideo, Uruguay. Tel

+598 248743 34, e-mail:mvilla@bilbo.edu.uy 
VILLAVEDRA, M.; CAROL, H. \& NIETO, A. - Evolution of IgG antibody response against Toxoplasma gondii tissue cyst in acute and chronic human infections. Rev. Inst. Med. trop. S. Paulo, 40(2): 77-84, 1998.

ME49 strain using sera (two with high and two with low titters of specific $\operatorname{IgG}$ ) but they did not report whether the patients were in chronic or acute infection.

More recently WOODISON et al. ${ }^{18}$ characterized, also by immunoblot (non-reducing conditions), the $\mathrm{Ab}$ response against tachyzoite (RH strain) and tissue cyst (human isolate "1869l") Ag in one accidentally infected patient (RH strain) and in 10 naturally infected patients. Also the information whether the patients were in chronlic or acute infection was lacking. However, these reports concluded that tissue cyst Ag (particularly a $17 \mathrm{kDa}$ band) were recognized only by sera from the chronic phase and suggested to be markers of this phase of infection.

In the present work, to establish the relationships between the stage of infection and the Ab response against specific Ag, the $\operatorname{IgG}$ response against tissue cyst (ME- 49 strain) and tachyzoite (RH strain) Ag were characterized, by immunoblotting under reducing conditions, in groups of naturally infected patients classified by serology at acute or chronic phase, as well as in two accidentally infected patients.

\section{MATERIALS AND METHODS}

Sera

A total of 65 serum samples were studied. Of these, fifty seven were from toxoplasmic human infections and eight were from healthy individuals. Fifteen serum samples corresponded to sequential bleedings from two accidentally infected patients, their features are detailed in Table 1. Seven serum samples correspond to Case $\mathrm{A}$, infected in the laboratory by spillage in the eyes, with a suspension of more than $10^{8}$ viable tachyzoite $/ \mathrm{ml}$ of $\mathrm{RH}$ strain. This patient had

TABLE 1

Serological data of the sequential serum samples collected from Cases A to E.

\begin{tabular}{|c|c|c|c|c|c|c|}
\hline \multirow{2}{*}{ Case } & \multirow{2}{*}{ Sample No. } & $\operatorname{Ig} G$ & $\operatorname{Ig} M$ & \multirow{2}{*}{$\begin{array}{l}\text { Days of } \\
\text { infection* }\end{array}$} & \multirow[b]{2}{*}{ Classification criteria } & \multirow{2}{*}{$\begin{array}{l}\text { Phase of } \\
\text { infection }\end{array}$} \\
\hline & & ELISA & ISAGA & & & \\
\hline \multirow[t]{7}{*}{$\mathrm{A}$} & 1 & $3.1 \pm 0.1$ & $(-)$ & 1 & Increase of $\operatorname{IgG}$ & Acute \\
\hline & 2 & $28 \pm 3$ & 12 & 22 & Increase of $\operatorname{IgG}, \operatorname{IgM}(+)$ & Acute \\
\hline & 3 & $105 \pm 7$ & 12 & 41 & Increase of $\operatorname{IgG}, \operatorname{IgM}(+)$ & Acute \\
\hline & 4 & $20 \pm 2$ & 11 & 174 & Decrease of IgG & Chronic \\
\hline & 5 & $21 \pm 2$ & 11 & 215 & Decrease of IgG & Chronic \\
\hline & 6 & $14 \pm 1$ & 10 & 257 & Decrease of $\operatorname{IgG}$ & Chronic \\
\hline & 7 & $41 \pm 4$ & 9 & 631 & 2 years of infection & Chronic \\
\hline \multirow[t]{8}{*}{ B } & 1 & $(-)$ & $(-)$ & 10 & Increase of IgG & Acute \\
\hline & 2 & $2.5 \pm 0.1$ & 12 & 16 & Increase of $\operatorname{IgG}, \operatorname{IgM}(+)$ & Acute \\
\hline & 3 & $29 \pm 2$ & 12 & 38 & Increase of $\operatorname{IgG}, \operatorname{IgM}(+)$ & Acute \\
\hline & 4 & $54 \pm 6$ & 12 & 52 & Increase of $\operatorname{IgG}, \operatorname{IgM}(+)$ & Acute \\
\hline & 5 & $100 \pm 12$ & 12 & 83 & Increase of $\operatorname{IgG}, \operatorname{IgM}(+)$ & Acute \\
\hline & 6 & $63 \pm 8$ & 12 & 114 & Decrease of IgG & Chronic \\
\hline & 7 & $59 \pm 2$ & 11 & 147 & Decrease of IgG & Chronic \\
\hline & 8 & $56 \pm 8$ & 11 & 179 & Decrease of IgG & Chronic \\
\hline \multirow[t]{4}{*}{$\mathrm{C}$} & 1 & $54 \pm 2$ & 12 & 0 & Increase of $\operatorname{IgG}, \operatorname{IgM}(+)$ & Acute \\
\hline & 2 & $226 \pm 8$ & 12 & 21 & Increase of $\operatorname{IgG}, \operatorname{IgM}(+)$ & Acute \\
\hline & 3 & $387 \pm 36$ & 12 & 55 & Increase of $\operatorname{IgG}, \operatorname{IgM}(+)$ & Acute \\
\hline & 4 & $141 \pm 8$ & 11 & 104 & Decrease of IgG & Chronic \\
\hline \multirow[t]{6}{*}{$\mathrm{D}$} & 1 & $541 \pm 37$ & 11 & 0 & Increase of $\operatorname{IgG}, \operatorname{IgM}(+)$ & Acute \\
\hline & 2 & $773 \pm 23$ & 11 & 20 & Increase of $\operatorname{IgG}, \operatorname{IgM}(+)$ & Acute \\
\hline & 2 & $2121 \pm 68$ & 11 & 56 & Increase of $\operatorname{IgG}, \operatorname{IgM}(+)$ & Acute \\
\hline & 4 & $484 \pm 77$ & 11 & 77 & Decrease of $\operatorname{IgG}$ & Chronic \\
\hline & 5 & $455 \pm 24$ & 11 & 91 & Decrease of $\operatorname{IgG}$ & Chronic \\
\hline & 6 & $125 \pm 18$ & 11 & 119 & Decrease of $\operatorname{IgG}$ & Chronic \\
\hline \multirow[t]{4}{*}{$\bar{E}$} & 1 & $412 \pm 60$ & 12 & 0 & Increase of $\operatorname{IgG}, \operatorname{IgM}(+)$ & Acute \\
\hline & 2 & $569 \pm 75$ & 12 & 42 & Increase of $\operatorname{IgG}, \operatorname{IgM}(+)$ & Acute \\
\hline & 3 & $1096 \pm 117$ & 12 & 69 & Increase of $\operatorname{IgG}, \operatorname{IgM}(+)$ & Acute \\
\hline & 4 & $1688 \pm 179$ & 12 & 105 & Increase of $\operatorname{IgG}, \operatorname{IgM}(+)$ & Acute \\
\hline
\end{tabular}

* For naturally infected patients it corresponds to days after first sample. 
VILLAVEDRA, M.; CAROL, H. \& NIETO, A. - Evolution of IgG antibody response against Toxoplasma gondii tissue cyst in acute and chronic human infections. Rev. Inst. Med. trop. S. Paulo, 40(2): 77-84, 1988.

high fever and adenopathy during approximately $1 \mathrm{wk}$. Eight serum samples correpond to Case B, infected in the laboratory by needlestick injury with a similar suspension. This patient reported no symptoms.

Fourteen sequential serum samples were obtained from three naturally infected patients (Cases C, D and E) and their data are detailed in Table 1.

Ten additional samples were classified as acute phase sera and 18 were classified as chronic phase sera. Their data are detailed in Table 2.

Serum samples were classified as from acute phase when they presented: a) increase of specific $\operatorname{IgG}$ and $\operatorname{IgM} \mathrm{Ab}, \mathrm{b}$ ) seroconvertion to positive. One sample from a pregnant woman carrying a recent infected fetus was also considered in acute phase.

Samples were classified as from chronic phase when they presented: a) specific $\operatorname{IgG} \mathrm{Ab}$ decrease, b) absence of specific IgM or c) infection course of more than 6 months.

Eight control serum samples showing negative results for both latex agglutination test (LBTex, Uruguay) and indirect ELISA (IgG) were obtained from healthy volunteers.

\section{Antigen (Ag) preparations}

Tissue cysts from ME-49 strain were purified by a modified method described by CORNELLISSEN, OVERDULVE \& HOENDERBOOM ${ }^{1}$. Brains from three mice with more than 3 months of toxoplasma infection were homogenized by 10 strokes in a Potter tube with six ml of PBS (0.15 M phosphate buffered saline, $\mathrm{pH}$ 7.2) with $40 \mu \mathrm{g} / \mathrm{ml}$ gentamicine sulfate. Isotonic Percoll (Pharmacia, Sweden) was added up to $45 \%(\mathrm{v} / \mathrm{v})$ and an autogenerated gradient was made by centrifugation at $20000 \mathrm{x} \mathrm{g}$ for 30 minutes at

TABLE 2

Serological data of the acute and chronic patients

\begin{tabular}{|c|c|c|c|}
\hline \multirow{2}{*}{$\begin{array}{l}\text { Phase of } \\
\text { infection }\end{array}$} & \multirow{2}{*}{$\begin{array}{c}\text { Sample } \\
\mathrm{Nr}\end{array}$} & $\operatorname{IgM}$ & \multirow[b]{2}{*}{ Classification criteria } \\
\hline & & ISAGA & \\
\hline \multirow[t]{10}{*}{ Acute } & 1 & 12 & Increase of $\operatorname{IgG}, \operatorname{IgM}(+)$ \\
\hline & 2 & 12 & Increase of $\operatorname{IgG}, \operatorname{IgM}(+)$ \\
\hline & 3 & 6 & Increase of $\operatorname{IgG}, \operatorname{IgM}(+)$ \\
\hline & 4 & 6 & Increase of $\operatorname{IgG}, \operatorname{IgM}(+)$ \\
\hline & 5 & 12 & Seroconvertion \\
\hline & 6 & 12 & Increase of $\operatorname{IgG}, \operatorname{IgM}(+)$ \\
\hline & 7 & 11 & Increase of $\operatorname{IgG}, \operatorname{IgM}(+)$ \\
\hline & 8 & 12 & $\begin{array}{c}\text { Pregnant woman with an } \\
\text { infected fetus }\end{array}$ \\
\hline & 9 & 12 & Seroconvertion \\
\hline & 10 & 12 & Increase of $\operatorname{IgG}, \operatorname{IgM}(+)$ \\
\hline \multirow[t]{18}{*}{ Chronic } & 1 & $(-)$ & $\operatorname{IgM}(-)$ \\
\hline & 2 & 9 & Decrease of IgG \\
\hline & 3 & 12 & Decrease of IgG \\
\hline & 4 & 12 & Decrease of IgG \\
\hline & 5 & $>8$ & Decrease of IgG \\
\hline & 6 & 9 & Decrease of IgG \\
\hline & 7 & 10 & $>6$ month of infection \\
\hline & 8 & $(-)$ & $\operatorname{IgM}(-)$ \\
\hline & 9 & $(-)$ & $\operatorname{Ig} M(-)$ \\
\hline & 10 & $(-)$ & $\operatorname{Ig} M(-)$ \\
\hline & 11 & 10 & Decrease of IgG \\
\hline & 12 & 7 & Decrease of $\mathrm{IgG}$ \\
\hline & 13 & $(-)$ & $\operatorname{Ig} M(-)$ \\
\hline & 14 & 12 & Decrease of $\operatorname{IgG}$ \\
\hline & 15 & $(-)$ & $\operatorname{Ig} M(-)$ \\
\hline & 16 & 11 & Decrease of $\operatorname{IgG}$ \\
\hline & 17 & $(-)$ & $\operatorname{IgM}(-)$ \\
\hline & 18 & $(-)$ & $\operatorname{Ig} M(-)$ \\
\hline
\end{tabular}


VILLAVEDRA, M.; CAROL, H. \& NIETO, A. - Evolution of IgG antibody response against Toxoplasma gondii tissue cyst in acute and chronic human infections. Rev. Inst. Med. trop. S. Paulo, 40(2): 77-84, 1998.

$15^{\circ} \mathrm{C}$. The fraction between $1063 \mathrm{~g} / \mathrm{l}$ and $1033 \mathrm{~g} / \mathrm{l}$ was collected, diluted in 3 volumes of PBS, and centrifuged at 8000 $\mathrm{x} g$ during 1 min. After 2 additional washings in PBS, the pellet was resuspended in SDS-PAGE sample buffer (approximately 350 tissue cyst $/ \mathrm{ml}$ ), boiled for 15 minutes and frozen at $-70^{\circ} \mathrm{C}$.

Brain tissue from healthy mice was treated following the same protocol of the infected brain tissue and was used as control $\mathrm{Ag}$.

Tachyzoites from Toxoplasma gondii (RH strain) were obtained as follows: adult swiss mice were inoculated i.p. with a mixture of $14 \times 10^{6} \mathrm{RH}$ tachyzoite and $11 \times 10^{6}$ sarcome cells (TG 180, ATCC) ${ }^{2}$. Four days later parasites in the peritoneal fluid were collected and the cavity was washed with $5 \mathrm{ml}$ of PBS. After three washes in PBS the pelleted tachyzoites were resuspended in SDS-PAGE sample buffer (approximately. $5 \times 10^{6}$ tachyzoite $/ \mathrm{ml}$ ), boiled for $15 \mathrm{~min}$ and frozen at $-70^{\circ} \mathrm{C}$.

\section{Immunoblotting}

SDS-PAGE (12\% resolving gels) of $2 \times 10^{3}$ purified tissue cysts and $5 \times 10^{6}$ tachyzoites per lane was carried out under reducing conditions, following standard protocols of the immunoblotting technique ${ }^{5,15}$. After electrophoresis was acomplished the gel was transblotted to nitrocellulose membrane (Schleicher and Schuell, Germany) for $70 \mathrm{~min}$ at 12 $\mathrm{V}$ in a semidry transfer apparatus (LKB, Sweden). The strips corresponding to the $\mathrm{Mr}$ standards were cut and stained with Amido Black while the remainder nitrocellulose membrane was blocked with $5 \%$ skimmed milk in PBS overnight at $4^{\circ} \mathrm{C}$, washed with PBS containing $0.1 \%$ Tween 20 (PBS-T) and cut into strips. Each serum sample was diluted 1/50 or $1 / 100$ in PBS-T containing $5 \%$ skimmed milk and $2 \%$ normal goat serum, and incubated with the nitrocellulose strips for $2 \mathrm{hr}$ at $37^{\circ} \mathrm{C}$ with gentle shaking. The strips were

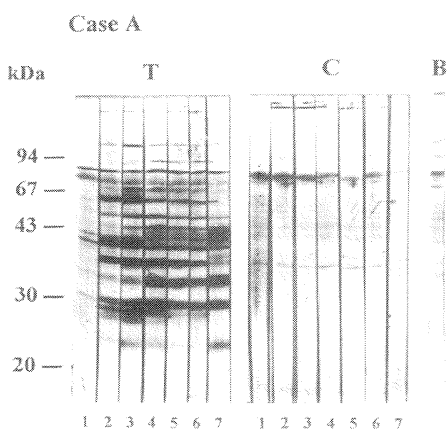

washed 3 times in PBS-T, for 20 minutes each. A goat antihuman $\operatorname{IgG}$ ( $\delta$ chain specific) alkaline phosphatase conjugate (Sigma, USA) was diluted in PBS-T containing 5\% skimmed milk and $2 \%$ normal goat serum, and incubated with the strips overnight at $4^{\circ} \mathrm{C}$ with continuous gentle shaking. The strips were washed as above, followed with PBS, and finally with $0.1 \mathrm{M}$ carbonate-bicarbonate buffer containing $1.0 \mathrm{mM}$ $\mathrm{MgCl}_{2}, \mathrm{pH}$ 9.8. The substrate solution NBT/BCIP was added and the color allowed to develop according to manufacturers instructions (Bio Rad, USA). Relative $M r$ estimates were calculated using regression analysis based on the $R f$ on the $M r$ standards in the corresponding nitrocellulose strips.

\section{RESULTS}

Both accidentally infected patients (Figure 1) showed a weak specific $\mathrm{IgG}$ response against tissue cyst $\mathrm{Ag}$. In Case A only two bands $(70 \mathrm{kDa}$ and $34 \mathrm{kDa})$ showed different reactivity from the normal brain control (Figure 1, Case A). The $70 \mathrm{kDa}$ band was strongly stained already in the first sample (as soon as $24 \mathrm{hr}$ ) after infection (Panel C, lane 1) and the $\mathrm{Ab}$ reaction against it only slightly diminished along 2 yr. of infection. The sera from the other accidentally infected patient recognized specifically only three Ags $(77 \mathrm{kDa}$, $63 \mathrm{kDa}$ and $58 \mathrm{kDa}$ ) (Figure 1 Case B). Several other bands from tissue cyst showed non-specific reactivity. They are present in each of the lanes transferred with normal brain (data not shown) and also, the first serum sample (specific $\mathrm{IgG}$ negative) reacts with these $\mathrm{Ag}$. These controls were performed in parallel for each serum sample and did not show any change along the period of the study. NC strips shown in the Figure 1 are representative.

The $\operatorname{IgG} \mathrm{Ab}$ response against tissue cyst $\mathrm{Ag}$ in the naturally infected patients started early during acute infection, showing a large variation both in intensity and pattern (Figure 2 and 4 ) and in some patients (as in the accidentally infected cases) the serum activity was weak (Figure 2). The

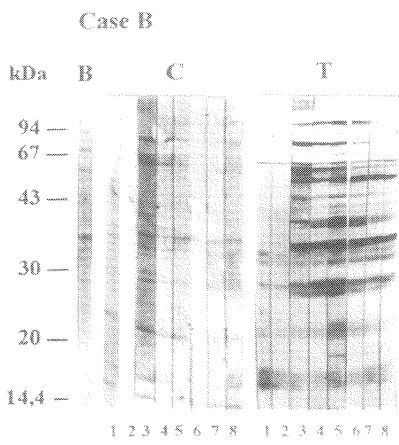

Fig.1 - Antigen recognition profiles by $\operatorname{IgG}$ in two accidentally infected patients (RH strain).

Case A (lanes 1 to 3 acute phase sera, lanes 4 to 7 chronic phase sera) and Case B (lanes 1 to 5 acute phase sera, lanes 6 to 8 chronic phase sera.)

Antigens from tachyzoite (T), tissue cysts (C) and brain from uninfected mice (B) were separated under reducing conditions. 
VILLAVEDRA, M.; CAROL, H. \& NIETO, A. - Evolution of $\operatorname{lgG}$ antibody response against Toxoplasma gondii tissue cyst in acute and chronic human infections. Rev. Inst. Med. trop. S. Paulo, 40(2): 77-84, 1988.
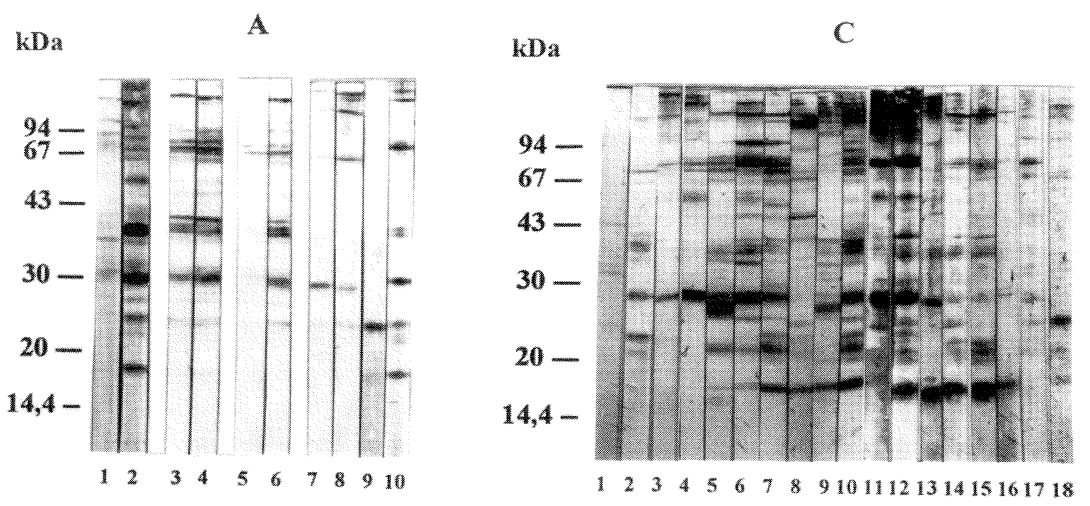

Fig. 2 - Tissue cyst antigen recognition profiles by sera from acute and chronic phase patients

Lanes 1 to 6 are three sequential serum pairs from acute phase patients and lanes 7 to 10 are four individual sera from acute phase patients (panel A). Lanes 1 to 18 are individual sera from chronic phase patients (panel C). Tissue cyst Ag was separated under reducing conditions.
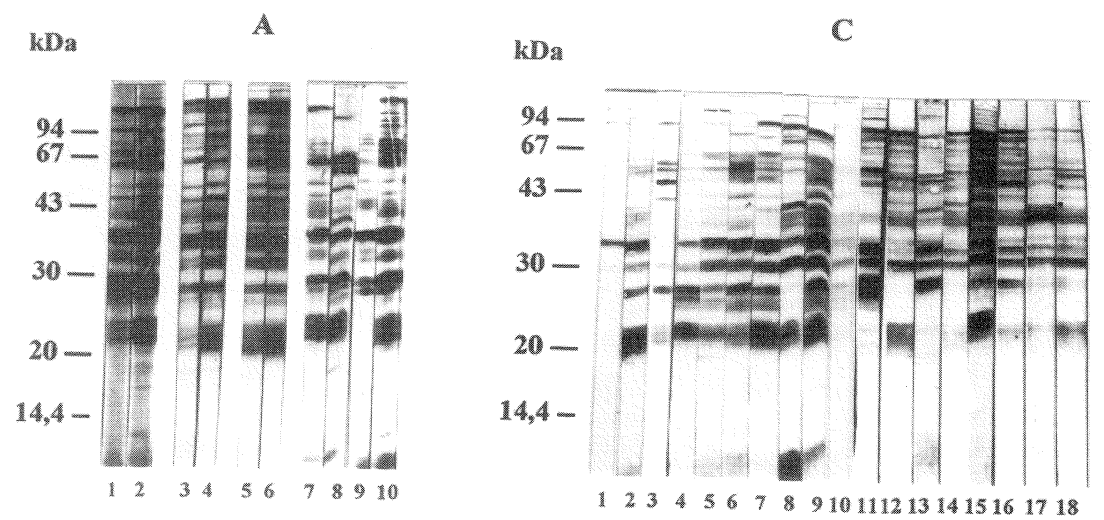

FIG. 3 - Tachyzoite antigen recognition profiles by IgG in sera from acute and chronic phase patients

Lanes 1 to 6 are three sequential serum pairs from acute phase patients and lanes 7 to 10 are four individual sera from acute phase patients (panel A). Lanes 1 to 18 are individual sera from chronic phase patients (panel C). Tachyzoit Ag was separated under reducing conditions.
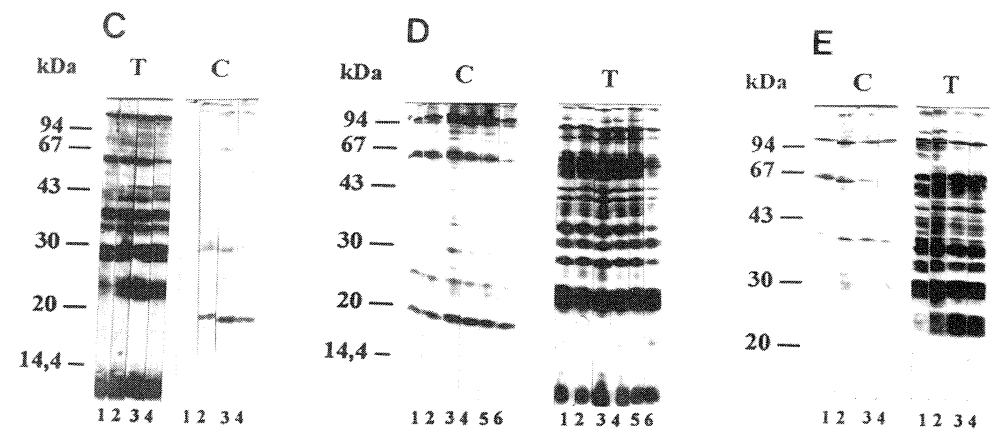

Fig. 4 - Evolution of the $\operatorname{IgG}$ antigen recognition profile in three naturally infected patients

Case C - Lanes 1 to 3 are sera from acute phase, lane 4 is a chronic phase serum. Case D - Lanes 1 to 3 are sera from acute phase, lanes 4 to 6 are sera from chronic phase. Case E - All sera correspond to acute phase. Ag from tachyzoite (T) and tissue cyst (C) were separated under reducing conditions. 
VILLAVEDRA, M.; CAROL, H. \& NIETO, A. - Evolution of IgG antibody response against Toxoplasma gondii tissue cyst in acute and chronic human infections. Rev. Inst. Med. trop. S. Paulo, 40(2): 77-84, 1998.

difference in the repertoire of tissue cyst $\mathrm{Ag}$ recognized is more important among different patients than among different times post infection (Figure 4) and in comparison to the response against tachyzoite $\mathrm{Ag}$ (Fig. 3), the antigenic pattern is less intense and broader.

The most important tissue cyst $\mathrm{Ag}$ recognized by the $\operatorname{IgG~} \mathrm{Ab}$ acute and chronic phase include four clusters in the ranges 20-24 $\mathrm{kDa}, 34-39 \mathrm{kDa}, 58-80 \mathrm{kDa}$ and $105-130 \mathrm{kDa}$, as well as two $\mathrm{Ag}$ of 18 and $29 \mathrm{kDa}$ (Figure 2). Six bands (between 82 and $151 \mathrm{kDa}$ ) are recognized exclusively by $\mathrm{IgG} \mathrm{Ab}$ of the chronic phase, but only that of $132 \mathrm{kDa}$ is recognized by more than $50 \%$ of the sera analysed (Figure 5). On the other hand, there are two bands (of 73 and 180 $\mathrm{kDa}$ ) recognized exclusively by $\operatorname{IgG}$ of the acute phase but both are positive only in eight percent of the samples.

The spectrum of tachyzoite Ag recognized by IgG from all the patients tested was very similar (Figure 3 and 4) whereas that of tissue cyst $\mathrm{Ag}$ was more diverse (figure 2 and 4). The different IgG responses against tachyzoite and tissue cyst Ag suggested that the dominant Ag are not shared by the two stages (Figure 2 and Figure 3 lanes 1 and 2, 5 and 6 in Panel $\mathrm{A}$ and 10 in Panel $\mathrm{C}$ ).

The tissue cyst Ag more frequently recognized (more than $50 \%$ of sera) by the population of chronic patients showed $M r$ of $132,64,58,28,25$ and $18 \mathrm{kDa}$ while those more frequently recognized by the acute patients exhibit $\mathrm{Mr}$ of $122,107,70,67,61,39,37,35,31,28,25$, and $23 \mathrm{kDa}$ respectively (Figure 2 and 5 ).

All the negative control sera showed a strong $\operatorname{IgG}$ reactivity to $44 \mathrm{kDa} \mathrm{Ag}$ present both in tachyzoite and tissue cyst $\mathrm{Ag}$ but not in the control $\mathrm{Ag}$, prepared from healthy mice brains (B). All sera also recognized, slightly, two Ag of 33 and $32 \mathrm{kDa}$ (data not shown).

\section{DISCUSSION}

The $\mathrm{IgG}$ response against tissue Ag during both accidental infections is weak probably due to the particularly low capacity of the RH Toxoplasma gondii strain to become encysted. This is consistent with results reported by WOODISON et al. ${ }^{18}$ and ZHANG et al. ${ }^{20}$. The tissue cyst Ag recognized by the accidentally infected patients showed similar $M r$ to those recognized in tachyzoite $\mathrm{Ag}$, and the presence of shared epitopes by the two stages of the parasite has to be further explored. The $\operatorname{IgG}$ response against the majority of the tissue cyst $\mathrm{Ag}$ recognized by the first serum sample of Case B (this serum sample is negative for specific IgG) is similar to the last collected sample. One of the interpretation may be that the IgGs detected are "natural Ab"; and another is the fact that the epitopes recognized are cross reactive and ubiquitous.

A peculiar response was observed in Case A against the $70 \mathrm{kDa}$ protein, strongly stained even one day after infection and decreasing during a period of $2 \mathrm{yr}$. This response could be against a heat shock protein (HSP) which was already present and thus having no direct relation with the $T$. gondii infection. This kind of proteins, evolutionary highly conserved but immunogenic, are expressed in cells exposed to a previous stress conditions of the patient involving or not infectious agents. The $70 \mathrm{kDa}$ HSP family (HSP70) has been well characterized in a number of protozoans, and particularly in Toxoplasma gondii, in which the HSP70 is expressed at high levels in tachyzoite from virulent strains ( $\mathrm{RH}$, ToxoENT and ToxoP) and is expressed slightly in tachyzoite from avirulent strains (Beverly and ME-49) grown in vivo in immunocompetent hosts ${ }^{7,10}$. Moreover, the first tissue cyst

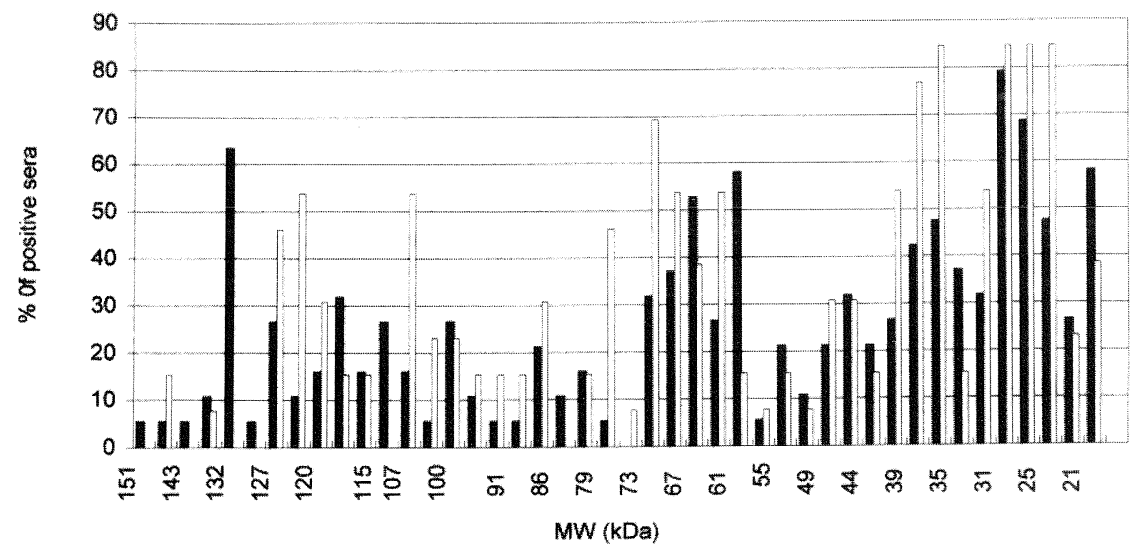

Fig. 5 - Relative frequencies (in percentages) of $\mathrm{IgG}$ recognition of tissue cyst $\mathrm{Ag}$ (separated under reducing conditions) in acute phase sera (open bars) and chronic phase sera (closed bars), from naturally infected patients, in a sample of 13 and 18 sera respectively. 
VILLAVEDRA, M.; CAROL, H. \& NIETO, A. - Evolution of IgG antibody response against Toxoplasma gondii tissue cyst in acute and chronic human infections. Rev. Inst. Med. trop. S. Paulo, 40(2): 77-84, 1988.

Ag recognized by sera from an $\mathrm{RH}$ strain accidentally infected patient, reported by WOODISON et al. ${ }^{18}$ is a $69 \mathrm{kDa}$ $\mathrm{Ag}$ which could be detected after 20 days of infection, which differs from our findings.

In contrast to results reported previously ${ }^{18,20}$, the tissue cyst specific IgG responses we found in the naturally infected patients are, in general, neither weak nor limited to a few Ag. They are present in acute phase and may appear as early as in the first month of the infection (Figure 2 panel A). They also differ greatly both in intensities and patterns of $\mathrm{Ag}$ recognized, either among individuals or phases (chronic and acute patients). Finally, the tisue cyst specific IgG response tends to build into a strong response in serum samples from chronic patients.

A pronounced $\operatorname{IgG}$ response against tachyzoite $\mathrm{Ag}$ was observed, in most of the studied patients, with no relevant changes throughout the infection.

Our data (exemplified by lanes 1 and 2, 5 and 6 from panels $\mathrm{A}$ and lane 10 from panels $\mathrm{C}$ in Figures 2 and 3) show that despite the overall coincidence of molecular weights between the most relevant Ags of thachyzoite and tissue cyst recognized by human infected sera, they can not be considered as identical molecules, as also observed in previous reports ${ }^{18,20}$.

In spite of the existence of $\operatorname{IgG}$ against tissue cyst antigenic bands that are more frequently present in our sample of acute patients (e.g. 122, 107, 75 and $69 \mathrm{kDa}$ ), we cannot conclude about a consistent pattern of Ag recognized by $\mathrm{IgG}$ $\mathrm{Ab}$ elicited during the acute phase of the infection. In general the patterns of $\mathrm{Ag}$ recognized by $\mathrm{IgG}$ from the different patients during the acute and chronic phases of the infection are similar despite the diversity of relative concentrations of Ab specific for different bands (Figure 5). We detected six tissue cyst Ag bands which seem to correlate to the chronic stage, but each band was only recognized by a low percentage of the serum samples tested, i.e. the most representative band was detected in as much as $60 \%$ of the samples. A combination of those bands could have potential value for the serological discrimination between acute and chronic phase. For example, taking together the reactivity towards the 132 $\mathrm{kDa}, 110 \mathrm{kDa}$ and $58 \mathrm{kDa}$ in chronic patients we achieved $90 \%$ of sensitivity and $87 \%$ of specificity. Nonetheless, due to the large number of different antigen bands with similar $\mathrm{Mr}$ and the practical difficulties in obtaining large quantities of tissue cyst of adequate purity, the serological discrimination by immunoblotting technique is seriously hampered. Purification of these relevant native antigens or preparation of recombinant $\mathrm{Ag}$ may be necessary to assess their diagnostic value in a larger number of samples, allowing eventually the development of a diagnostic procedure.

WOODISON et al. ${ }^{17}$ described three tissue cyst Ag (25,
36 and $67 \mathrm{kDa}$ ) shared by three different strains of Toxoplasma gondii, and recognized by many human sera. These Ags are apparently shared by the ME-49 strain and are recognized by the majority of our sera.

We found that the $18 \mathrm{kDa} \mathrm{Ag}$, corresponding to the reported $^{18} 17 \mathrm{kDa}$ with potential for discriminative serodiagnosis, is specifically recognized in tissue cyst by both groups of patients $(58 \%$ of the chronic patients and $38 \%$ of the acute patients). Thus, it seems that this band is not useful for the serodiagnosis of human chronic infection. Moreover, our results show that the $69 \mathrm{kDa} \mathrm{Ag}$, previously described as one of the most important Ag during chronic infection ${ }^{18}$, is actually relevant in acute infection as well. These discrepancies could be explained by several factors as: a) immunological status does not always fit with the parasitological shift between acute and chronic phases; b) important individual variations, being emphasized when few serum samples are assayed; c) influence of different geographical distribution of strain; and d) different sensitivities achieved in the techniques used.

Our results show that the antibody response for each individual against tissue cyst $\mathrm{Ag}$ is almost the same during the period of this study (Figure 4). Thus, the differences in the $\mathrm{IgG}$ response against tissue cyst $\mathrm{Ag}$ in naturally infected patients are probably due to strain difference of Toxoplasma gondii, with different capacity to produce tissue cyst. The profile variations we observed in tissue cyst stained by specific IgG Ab suggest to depend on the cystogenic capacity of the infective organism rather than on the poor immunogenicity of the cyst $\mathrm{Ag}$ and/or the absence of properly exposed epitopes ${ }^{18}$

In order to identify a tissue cyst Ag which could be useful to discriminate between acute and chronic infection we need to define more precisely the limit, i.e. time course for the acute infection. PCR techniques could be appropriate to define the parasitological status of the infection. The results here reported may reflect the coexistence of tachyzoite and tissue cyst during acute infection and/or that there is an important delay between the real end of the acute infection and the time when indirect diagnostic methods can detect it. In the majority of human cases, the chronic infection can be established by serologic criteria 2 or 3 months after infection occurred. This period should be more than enough for an immunocompetent patient to mount an efficient immune response that would drive the parasite to encyst. The strong response against tachyzoite Ag detectable for more than $1 \mathrm{yr}$, after infection, and the weak crossreactivity between the Ag of different stages points to the coexistence of tachyzoite and tissue cyst during the chronic infection as well, or alternatively the persistence of tachyzoite $\mathrm{Ag}$ on dendritic cells for prolonged periods. Whether or not this situation is favou-red by the parasite and bears any benefit for its survival merits further studies. 
VILLAVEDRA, M.; CAROL, H. \& NIETO, A. - Evolution of IgG antibody response against Toxoplasma gondii tissue cyst in acute and chronic human infections. Rev. Inst. Med. trop. S. Paulo, 40(2): 77-84, 1998.

\section{RESUMO}

Evolução da resposta por anticorpos IgG contra cistos tissulares do Toxoplasma gondii em infecções humanas agudas e crônicas

O reconhecimento do perfil dos antígenos de cistos tissulares pelos anticorpos $\operatorname{IgG}$ foi estudado durante a infecção toxoplasmótica aguda e crônica. Assim a resposta de IgG contra Toxoplasma gondii foi investigada pelo "immunoblotting" em dois pacientes acidentalmente infectados com a variedade $\mathrm{RH}$ bem como em grupos de pacientes naturalmente infectados nas fases aguda e crônica. Houve uma coincidência global da massa molecular entre antígenos de taquizoitas e cistos tissulares reconhecidos por estes soros, todavia, eles parecem não ser as mesmas moléculas. A resposta contra cistos tissulares começa precocemente durante a infecção aguda e a reatividade de anticorpos é forte contra ampla variedade de antígenos. Seis faixas (entre 82 e $151 \mathrm{kDA}$ ) foram reconhecidas exclusivamente pelos soros da fase crônica mas somente as faixas de $132 \mathrm{kDA}$ foram positivas em mais de $50 \%$ dos soros analisados. Uma mistura destes antígenos poderia ser usada para distinguir entre as duas fases da infecção. Os antígenos mais importantes reconhecidos nos soros das fases agudas e crônicas foram 4 grupos com intervalos de 20-24 kDa, 34-39 kDa, 58-80 kDa e 105-130 kDa bem como dois antígenos adicionais de 18 e $29 \mathrm{kDa}$. Ambos pacientes infectados acidentalmente e alguns dos pacientes naturalmente infectados mostraram fraca resposta específica contra os antígenos de cistos tissulares.

\section{ACKNOWLEDGEMENTS}

Acknowledgements are due to Dr. David S. Lindsay, Department os Pathobiology, Auburn University, Alabama, USA, for providing the ME-49 strain of Toxoplasma gondii. To Pablo Agratti, M. Elena Vega, Ana Combolt and Dra Piazza, for providing the sera of acute and chronic patients.

This work was supported by CSIC, Universidad de la República (Uruguay), PEDECIBA (UNDP Project URU/94/ 002), Swedish Agency for Research and Cooperation (SAREC) and RELACIN/UNESCO.

\section{REFERENCES}

1. CORNELISSEN, J.P.; OVERDULVE, J.P. \& HOENDERBOOM, J.M. - Separation of Isospora (toxoplasma) gondii cysts and Cystozoites from mouse brain tissue by continuous density-gradient centrifugation. Parasitology, 83: 103-108, 1981.

2. COUZINEAU, P. \& BEAUfINE-DUCROCQ, H. - Étude des possibilités d'utilisation du sarcome TG180 de la souris. Application á la toxoplasmose. Ann. Parasit. hum. comp., 44: 217-224, 1969.

3. HANDMAN, E.; GODING, J.W. \& REMINGTON, S. - Detection and characterisation of membrane antigens of Toxoplasma gondii.
J. Immunol., 124: 2578-2583, 1980.

4. KASPER, L.H. - Identification of stage-specific antigens of Toxoplasma gondii. Infect. Immun., 57: 668-672, 1989.

5. LAEMMLI, U.K. - Cleavage of structural proteins during the assembly of the head of bacteriophage T4. Nature (Lond.), 227: 680-685, 1970.

6. LUNDE, M.N. \& JACOBS, L. - Antigenics differences between endozoites and cystozoites of Toxoplasma gondii. J. Parasit., 69: 806-808, 1983.

7. LYONS, R.E. \& JOHNSON, A.M. - Heat shock proteins of Toxoplasma gondii. Paras. Immunol., 17: 353-359, 1995.

8. MAKIOKA, A.; SUZUKI, Y. \& KOBAYASHI, A. - Recognition of tachyzoites and bradyzoite antigens of Toxoplasma gondii by infected hosts. Infect. Immun., 59: 2763-2766, 1991.

9. PARTANEN, P.; TURUNEN, H.J.; PAASIVUO, R. et al. - Identification of antigenic components of Toxoplasma gondii by an immunoblotting technique. FEBS Lett., 158: 252-254, 1983.

10. POLLA. B.S. - Heat shock proteins in host-parasite interactions Immunol. today, 12: A38-A41, 1991.

11. SHARMA, S.D.; MULLENAX, F.G.; ARAUJO, F.G.; ERLICH, H.A. \& REMINGTON, J.S. - Western blot analysis of the antigens of Toxoplasma gondii recognised by human IgM and IgG antibodies. J. Immunol., 131: 977-983, 1983.

12. SUZUKI, Y. \& REMINGTON, J.S. - Toxoplasmic encephalitis in AIDS patients and experimental models for study of the disease and its treatment. Res. Immunol., 144: 66-67, 1993.

13. SUZUKI, Y.; THULLIEZ, P.; DESMONTS, G. \& REMINGTON, J.S. - Antigen(s) responsible for immunoglobulin $G$ responses specific for the acute stage of Toxoplasma infection in humans. J. clin. Microbiol, 26: 901-905, 1988

14. TOMAVO, S.; FOSTIER, B.; SOETE, M. et al. - Characterization of bradyzoite-specific antigens of Toxoplasma gondii. Infect. Immun., 59: 3750-3753, 1991.

15. TSANG, V.C.; PERALTA, J.M. \& SIMONS, A.R. - Enzyme-linked immunoelectrotransfer blot techniques (EITB) for studying the specificities of antigens and antibodies separated by gel electrophoresis. Meth. Enzymol., 92: 377-391, 1983.

16. VERHOFSTEDE, C.; VAN GELDER, P. \& RABAEY, M. - The infection-stage-related IgG reponse to Toxoplasma gondii studied by immunoblotting. Parasit. Res., 74: 516-520, 1988.

17. WOODISON, G. \& SMITH, J.E. - Identification of dominant cyst antigens of Toxoplasma gondii. Parasitology, 100: 389-392, 1990.

18. WOODISON, G.; BALFOUR, A.H. \& SMITH, J.E. - Sequential reactivity of serum against cyst antigens in Toxoplasma infection. J. clin. Path., 46: 548-550, 1993.

19. ZHANG, Y.W. \& SMITH, J.E. - Toxoplasma gondii: reactivity of murine sera against tachyzoite and cyst antigens via FAST-ELISA. Int. J. Parasit., 25: 637-640, 1995a.

20. ZHANG, Y.W.; FRASER, A.; BALFOUR, A.H. et al. - Serological reactivity against cyst and tachyzoite antigens of Toxoplasma gondii - determined by FAST-ELISA. J. clin. Path., 48: 908-911, 1995b.

Recebido para publicação em 27/06/1997 Aceito para publicação em 20/02/1998 